p. 416 , to show that a mixture of Ferndale dust and air is probably explosive, but the Ferndale dust mentioned in my papers and book is from the anthracite seams, and it is generally admitted now that anthracite dusts and air are not explosive when unmixed with firedamp.

I think readers of NATURE will agree that it is not permissible to quote half a paragraph when the rest of it amplifies.

Chemical Laboratory, Liverpool University.

We take exception to Dr. Harger's statements, in the quotation which he gives from p. 78 of his book, that "dust explosions" such as Altofts "always proceed against the current of air," and that, "as a rule, the branch of an ignition which travels with the air-current fails to develop violence."

The explosion at Altofts travelled to a distance of more than a mile in No. I chain road in the same direction as the air current had been previously travelling, and produced a greater amount of wreckage in that heading than in any other part of the mine. It did not reach the faces at any point, nor did it enter the return airways, for the reasons plainly set forth in Proc. Rov. Soc., vol. xlii., p. I74.

In our experience explosions are invariably found to have penetrated into the faces wherever there has been an uninterrupted train of coal-dust leading to them; and they have, as a rule, failed to pass through the return airways where the latter have not been recently used as haulage roads, and where, consequently, the coal-dust has become mixed with a large proportion of shale dust. For instance, the composition of a sample of dust taken from the return airwars at Altofts Colliery after the explosion was as follows :-

$\begin{array}{lcccccc}\text { Moisture } & \ldots & \ldots & \ldots & & & \text { Per rent } \\ \text { Volatile matter other than } & \ldots & \ldots & 4.40 \\ \text { Carbon } & \text { (estimated) } & \ldots & \ldots & \ldots & 15.64 \\ \text { Ash } \ldots & \ldots & \ldots & \ldots & \ldots & \ldots & 69.59\end{array}$

The experiments since made, both at Altofts and Lićvin, have shown that dust of this quality is incapable of propagating an explosion.

The reference to Proc." Roy. Soc., vol. xxviii., p. $4 \mathrm{I} 6$, in the review, was not intended to show that a mixture of Ferndale dust and air "is probably explosive," as Dr. Harger suggests, but that return air does not contain too little oxygen or too much carbon dioxide to prevent its ignition when mixed with coal-dust even of the same quality as that of Ferndale. There are no anthracite seams in Ferndale Colliery; all the seams consist of steam coal of high-class quality.

The Reviewer.

\section{Error in the Smithsonian Physical Tables.}

I HAVE just discovered a very awkward error in Table 47, p. 35, of this valuable publication. The table is headed "Least Squares," and gives the values of the probability integral. 'To illustrate the error, an example will be best.

For argument 0.53 , the table gives 0.55494 , but this is really the value for the argument 0.54 , and the same error runs throughout the table. An easy way to correct it is to increase by o.or each of the figures in the horizontal line heading the table.

My copy is dated 1896 , and I do not know if the mistake has been set right since.

I am reminded that some years ago I wrote to NATURE to suggest that all discovered errors in tables should be sent to some official scientific body, which should annually publish corrections of them.

Hyde Park, Leeds, May 22.

$$
\text { C. T. Whitmel. }
$$

\section{ANTHROPOLOGY IN WEST AFRICA. ${ }^{1}$}

$\mathrm{W}^{\mathrm{n}}$ E welcome a report by $\mathrm{Mr}$. N. W. Thomas on the people of the Awka district, Ibo country, Southern Nigeria. Mr. Thomas is the Government anthropologist and has already given us an interesting report on the Edo-speaking people.

The present report is divided into three parts; the first treats of the law and customs of the people, the second is a dictionary, and the third contains proverbs, narratives, and vocabularies.

The most interesting to the general reader is undoubtedly part i. In chapter ii. Mr. Thomas gives some most interesting demographic facts and figures. Referring to infanticide, he says :-

In addition to this legal infanticide (the exposure of twins) . . I I have more than once heard that the first-born of every woman is killed; my informants were Roman Catholic missionaries, who certainly know the native and his ways, and my own statistics seem to bear out the statement.

This is very interesting, and bears out the principle common, evidently, to most West Africans, that the first-born belongs to the owner of the family (i.e. the dead facher). He, as head of the family, is worshipped by his son, grandson, great-grandson, and great-great-grandson. He (the dead one) has need of followers in dead man's land, and claims this toll in exactly the same way as the owner of a goat will claim its first-born from the farmer who is looking after it for him.

The genealogical tables are of great interest, and, in spite of the fact that the number of wives to one husband varies from four to eight, "the proportion of boys to girls in the births was fifteen to eleven." But there are more grown-up females than males. Taking the statistics for living males and females among the Ibo (1218 males to I340 females), we can only conclude that the mortality among boys is greater than among girls or that this majority is largely composed of widows. That husbands in such a country should have four to eight wives must deprive a great number of men of the luxury of a wife. Many chiefs tacitly acknowledge this want and have appointed females in each town or village to supply the need. But in spite of this precaution young bachelors are constantly committing adultery. Men with one wife in this district account for 760 male and 787 female children, men with four wives for I 37 male and I 3 females. This chapter is most instructive to those who are interested in the question of polygamy versus monogamy.

Chapter iii. is entitled "Religion," and, written by such a master of anthropology as Mr. Thomas, is a lesson to all students of religion in Africa. Those of our readers who have followed the development of this great colony will not have forgotten the suppression of the so-called juju at 1 " Anthropological Report on the Ibo-speaking Peoples of Nigeria." By
N. W. Thomas. Part i., Law and Customs of the Ibo of the Awka Neigbbourhood, S. Nigeria. Pp. $16 x+x x$ plates. Part ii., Englısh-Ibo and Ibo-English Dictionary. Pp. vii +30 r. Part iii., Proverbs, Narratives, Vocabularies, and Grammar. Pp. vitrgg. (London: Harrison and Sons, I913.) 
Aro Chuku and the recent recrudescence of the horrible rites nipped in the bud by the District Commissioner. Mr. Thomas writes: "We have,

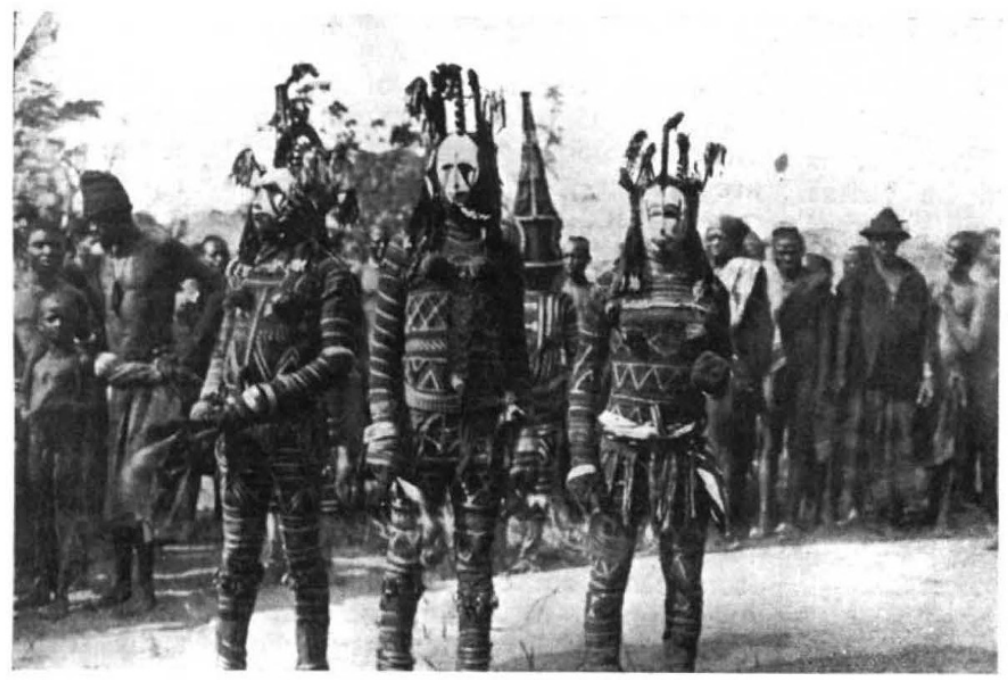

FIG. I,-Mauri. From "Anthropological Report on the lbo-speaking Peoples of Nigeria." ship. At any rate, if the chief of Uri is not yet a king, it would appear that he, as a great spiritual leader, is on his way to kingship if his progress is not interfered with.

It is impossible to do justice to this part of Mr. Thomas's report in the space available. All his chapters are intensely interesting.

Part ii. is the dictionary, the material for which was, $\mathrm{Mr}$. Thomas says, collected in I9I I from natives of Awka and Onitsha. It seems a pity that the vast and interesting material collected by the various missionary societies has not been taken into account. They must have dictionaries, at any rate in manuscript, and they have made translations in the Ibo language. We notice that Onitsha is spelt Oniča, and that Mr. Thomas, instead of adopting the geographical system of spelling as officially gazetted, has given us a it is true, at the head of the pantheon a supreme system of his own-a good one, no doubt, but god known as Cuku," who "seldom appears to a new one. There are thus three systems of figure in creation myths." The old men say that writing in Nigeria-the system adopted by the they knew nothing of $\mathrm{Cuku}$ before the coming of the white man. This may be quite correct, for our experience is that the idea of a supreme god is seldom reached by people living in the clan stage. To have a god like the Yoruba Olorun, or the Bini Osalubwa, people must have reached the kingdom stage of development. If the Aro Chuku juju had not been suppressed it is possible that the Ibos would be well on their way in their development of a great Ibo kingdom under the supreme god Chuku. It is rather remarkable th at a trained anthropologist like Mr. Thomas should call the chief of Uri king in his chapter on priestly kings. The father of

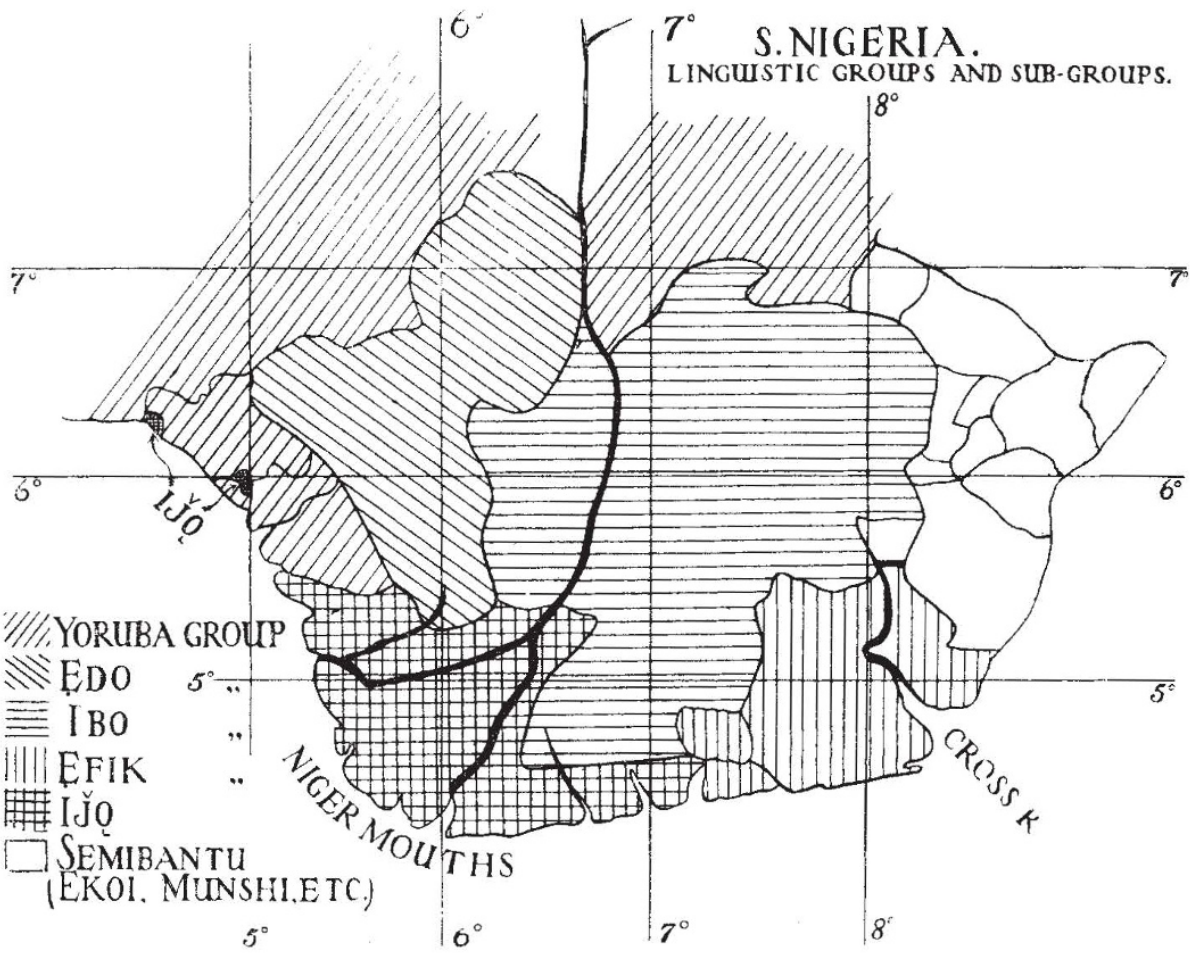

F1G. 2.-From "Anthropological Report on the Ibo-speaking Peoples of Nigeria."

the family prays for his people, the head of the house does the same, the elected judge or head of a number of clans, or a tribe, does the same. The priestly office is there, but surely not kingNO. 2274 , VOL. 9I] missionaries, the system enforced on officials by the Government, and Mr. Thomas's system.

Mr. Thomas has shown his caution by omitting the words "God" and "Cuku" from his dictionary. 
There are no words beginning with the English $c$ sound in the dictionary, and all the words under $\check{c}$ in the dictionary are to be pronounced $t c h$, or as the $c$ in "church." Why, then, should not the simple $c$ stand for this sound? The new $c$ seems unnecessary.

The letter $j$ is to be pronounced as $j$ in "judge," but it is to be written $j$. In the Yoruba dictionary the sound $s h$ is written $s$. This $\operatorname{sign}, \mathrm{Mr}$. Thomas says, stands for the cerebral $s$, and he writes the $s h$ sound $v$ instead of $s$. There will be great gnashing of teeth in Nigeria until the Grovernment takes the matter up and appoints a commission to settle which system is to be maintained.

Part iii.-Needless to say, Mr. Thomas has treated the proverbs, narratives, and grammar scientifically. The folklorist will revel in them. The student of the Ibo language will be greatly helped by the literal translations of the stories and by the vocabularies.

Mr. Thomas divides the languages in Southern Nigeria into four groups.

(a) Yoruba with Igara and Sekri (Jekri).

(b) Edo (Ado), including Sobo, Bini, Kukuruku, and Esa (Ishan).

(c) Ibo with Ika and numerous other languages.

(d) Efik and Ibibio.

The Government of Southern Nigeria is to be congratulated on the production of these valuable reports by its Government anthropologist, and we hope that $\mathrm{Mr}$. Thomas will soon give us equally interesting books about the Ibibios and Efiks.

\section{THE INTERNATIONAL ASSOCIATION OF ACADEMIES.}

THE fifth meeting of the International Associa1 tion of Academies was held at St. Petersburg during Whit-week. Of the twenty-two academies which constitute the association, twenty-one took part in the proceedings, the British Academy being the only society which was not represented. The delegates of the Royal Society were: Sir David Prain, Prof. Arthur Schuster, Prof. Sherrington, and Prof. Turner.

Among the new proposals the most important was that submitted by the Berlin Academy for an international investigation of the problems connected with volcanoes. It is not intended to form an international institute similar to that for geodesy or seismology, but rather to encourage each country to take its share in the investigation by establishing, if desirable, a separate institute of its own. An autonomous commission of the International Association of Academies could then act as connecting link between the different institutions. A small committee was nominated to make more definite proposals to the next assembly, and was authorised to enter into communication with the separate academies, each being asked to nominate a representative, and thus form a larger body to assist the committee in formulating a scheme of joint investigation.

An interesting proposal came from the Imperial Academy of St. Petersburg. The want is appar- ently felt in several branches of science to have a more scientific scale and definition of compound colours than exists at present. It ought to be possible to define the colour, e.g., of a particular leaf, the skin of an animal, or a new chemical compound in such a way that everyone could obtain an accurate idea of it. Books, containing numbered samples of the different shades of the various colours, suffer from the defect that they are subject to change; and though in practice it may be found necessary to use such books as secondary standards, some means should be found to compare them from time to time with a more scientific scale of colours. The committee appointed to discuss this question consists of : Prince Galitzin, Sir Wm. Abney, and Messrs. Nasonow, Saccardo, Schuster, and Walden.

It has become the habit of the association to give its moral support to undertakings which it considers valuable; such support often enabling those more directly interested in them to obtain from other sources the financial help they need. A proposal to encourage in this fashion an organisation instituted at Frankfort by Prof. Brendel for calculating the orbits of small planets was adopted on the motion of the Académie des Sciences of Paris.

An enterprise to publish annually a table of physico-chemical constants had already been supported at the meeting at Rome; and though the utility of the work was subjected to some criticisms, it appeared that there was a real demand for it, and it received renewed support at the present assembly.

A report was presented by Prof. Turner on the progress of the work connected with the nomenclature of features on the surface of the moon. Although the committee has suffered much through the deaths of Prof. Franz and Mr. Saunders, there is good hope that the work will soon be completed and prove a most useful help to students of lunar phenomena.

A question of wider interest was raised by the French proposal to discuss the possibility of a reform of the calendar. This includes not only the question of fixing the date of Easter, but also more sweeping changes intended to divide the year into four equal quarters (at present the first six months consist of $\mathrm{r} 8 \mathrm{I}$ and the second six months of 184 days) and the intercalation of an occasional extra day in the week, introduced to secure that the same day in each year should always be associated with the same day of the week. A committee was appointed to consider this matter.

The above, referring entirely to the work of the section of science, does not exhaust the questions which were raised and discussed before that section. The section of letters also had a successful meeting.

The association is still young, and consequently has to devote some attention to the statutes and regulations for its procedure, which have not yet become crystallised. A proposal to appoint a permanent secretary was strongly supported by some and opposed by other academies. It will 